IVICA ŠEGULJA, Ph.D.

\title{
MAINTENANCE INTERVAL ADJUSTMENT OF SIGNIFICANT SHIP PROPULSION COMPONENTS
}

\begin{abstract}
The traditional marine maintenance concept based on individual equipment manufacturer's recommendations does not represent the most efficient maintenance strategy. Suggested manufacturer's intervals can be modified due to a great number of factors that influence the condition and the component performance. In work [1] the model for defining and adjustment maintenance strategy onboard ships was developed, assuring the required level of safety and the lowest lifecycle cost. The present model for adjusting the maintenance interval of significant items is part of this model, which has been verified on real data from thirteen years of experience. The results obtained by the model are different from the data suggested by the manufacturer.
\end{abstract}

\section{KEYWORDS}

maintenance, diesel-engine propulsion system, significant items, maintenance interval adjustment, failure rate, time between failures, maintenance interval adjustment of exhaust valve

\section{INTRODUCTION}

Ship equipment manufacturers mainly propose a preventive maintenance strategy based on the working hours of their equipment. The on-time maintenance concept, which is generally used aboard ships, does not represent the most efficient maintenance strategy. The suggested manufacturer's intervals can be modified due to a number of factors that influence the condition and the component performance.

In paper [1] a model for defining and adjustment of maintenance concept onboard ships was developed, assuring the required level of safety and the lowest lifecycle cost. The model consists of several steps, and the final result is the maintenance concept for the ship and its equipment. The ship is decomposed into constituents, downward to the lowest level of equipment functionalism. Similar devices in terms of function and working principles are classified as item type. For each item type the failure mode/cause combination (FMCC) is described and recorded in the database. The procedure has been defined of how risk analysis can be used to select the maintenance concept. Since the entire adjustment and design model is huge, and a part of it is used as a model for adjusting the maintenance interval of significant components.

\section{MAINTENANCE INTERVAL ADJUSTMENT MODEL}

Figure 1 shows a model for the maintenance interval adjustment which consists of two parts:

1. The ship - the machinery behaviour is monitored, a database is formed and sent to the office. Daily reports on the machinery are recorded into the logbook during 24 hours. Data about failures and maintenance activities are entered, as well as the duration of the breakdown. The operator has full responsibility for entering information about the equipment behaviour, and is also responsible for clear and precise information.

2. The office - uses the database, performs data analysis and adjusts (models) the maintenance intervals. The office collects all the data received from the entire fleet, and has responsibility for modification of maintenance intervals. In some cases the modification can be done by ship engine crew, but more precise data analysis can be done on shore because they can compare the data received from several ships. During the analysis of maintenance parameters, specific characteristics for each ship have to be accounted for. If some maintenance parameters have been changed, all the sister ships should be informed.

The procedure includes the following steps:

2.1 Operational data - contain components data per cylinder, propulsion engine working hours, time between failures (TBF), condition and failure description. 


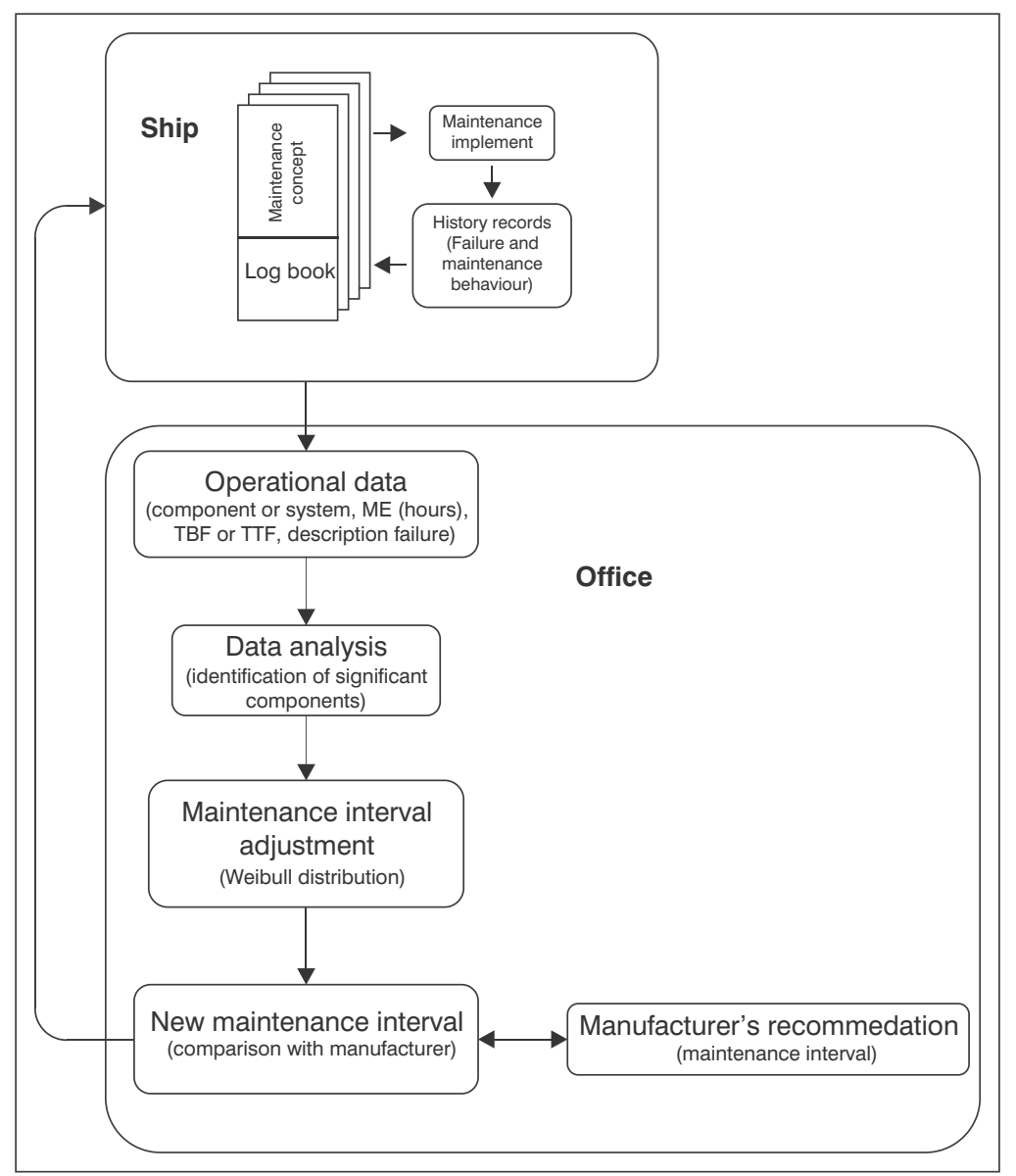

Figure 1 - Maintenance interval adjustment

2.2 Data analysis - significant components are defined. Within significant components according to significant failure effects significant failure modes are identified. Failure mode is defined as the manner in which a failure is observed; it generally describes the way the failure occurs. Failure effect represents immediate consequences of a failure on the operation, function or functionality, or status of an item (e. g. impurity in fuel, exhaust gases, water content, no lubrication).

2.3 Maintenance interval adjustment - from the given data, shape parameter $\beta$ and scale parameter $\eta$ of Weibull distribution can be defined and the predictability of failure $p$. Based on these data maintenance interval adjustment can be done.

\section{SHIP PROPULSION SYSTEM}

Diesel-engine propulsion system with a gearbox is chosen for the research. The propulsion system consists of a diesel engine MAN 7L 400/500 power $\cong 2200$ kW (3000 HP), the gearbox and a shaft with the ship propeller. The gearbox type Renk that reduces the rotation speed of the propulsion engine of $430 \mathrm{~min}^{-1}$ to the rotation speed of the ship propeller of $185 \mathrm{~min}^{-1}(i$ $=430 / 185 \cong 2.3$ ). The propulsion engine daily reports are recorded into the log book, which is run every day from 00 to 24 hours in seaway and stay in the port. The research is based on the original failure data and maintenance activities in case of a breakdown of the propulsion engine operation during a period of thirteen years [2]. Maintenance costs are not known in the research.

The logbook of historical data consists of:

\begin{tabular}{||l|l||}
\hline Component & $\begin{array}{l}\text { Identification of significant compo- } \\
\text { nents from historic data }\end{array}$ \\
\hline Cylinder & $\begin{array}{l}\text { Cylinder on which maintenance ac- } \\
\text { tion is performed or preventive re- } \\
\text { placement }\end{array}$ \\
\hline PE hours & Working hours of propulsion engine \\
\hline Condition & $\begin{array}{l}\text { Failure mode (burned seal, broken) } \\
\text { or '-' nothing in logbook or preven- } \\
\text { tive replacement of a component }\end{array}$ \\
\hline Hours & $\begin{array}{l}\text { Working hours of component. After } \\
\text { intervention the assumption is that } \\
\text { the replaced component is "as new" }\end{array}$ \\
\hline Description & $\begin{array}{l}\text { Short description of failure or main- } \\
\text { tenance activity }\end{array}$ \\
\hline
\end{tabular}




\section{FAILURE ANALYSIS}

Failure occurrence results in case of the mentioned propulsion system are described in [1,3]. The survey of the analysis of the most intensively recorded components, where a functional failure is identified, is shown in Table 1. Records for the exhaust valves are most numerous. Out of 62 replacements of exhaust valves in pairs, there were 30 cases of functional failures registered (burnt, blowout, corrosion, leakage,

Table 1 - Survey of the functional failure of the components

\begin{tabular}{|c|c|c|}
\hline Component & \multicolumn{2}{|c|}{ Functional failure } \\
\hline \multirow{5}{*}{ Injection valve } & unit for cooling & 1 \\
\hline & blockage & 1 \\
\hline & bad work & 1 \\
\hline & spring & 1 \\
\hline & Total & 4 \\
\hline \multirow{7}{*}{ Exhaust valve } & housing deposits & 1 \\
\hline & burnt valve & 19 \\
\hline & blow-out valve disc & 5 \\
\hline & damaged valve & 1 \\
\hline & seat erosion & 2 \\
\hline & leakage valve & 2 \\
\hline & Total & 30 \\
\hline \multirow{3}{*}{ Inlet valve } & burnt valve & 2 \\
\hline & damaged valve & 1 \\
\hline & Total & 3 \\
\hline \multirow{4}{*}{ Fuel oil pump } & thrust plate & 3 \\
\hline & leakage pump cover & 3 \\
\hline & plug replacement & 1 \\
\hline & Total & 7 \\
\hline
\end{tabular}

Table 2 - Failure rate for propulsion engine MAN 7L 400/500

\begin{tabular}{|l|c||}
\hline \multicolumn{1}{|c|}{ Component (system) } & Failure rate $\left[\right.$ hour $^{-1}$ ] \\
\hline Fuel oil system & $0.1136 \cdot 10^{-3}$ \\
- fuel oil pump & $0.0487 \cdot 10^{-3}$ \\
- fuel oil high-pressure pipe & $0.0649 \cdot 10^{-3}$ \\
- injection valve & $0.4870 \cdot 10^{-3}$ \\
Exhaust valve & $0.0487 \cdot 10^{-3}$ \\
Inlet valve & $0.1623 \cdot 10^{-3}$ \\
Lubrication system & $0.2272 \cdot 10^{-3}$ \\
Cooling system & $0.1298 \cdot 10^{-3}$ \\
Other & $1.2822 \cdot 10-3$ \\
\hline Total failure rate & \\
\hline
\end{tabular}

deposits), that is $\approx 50 \%$. The most were burnt valves (19), followed by blow-out valves (5).

The failure rates are presented in Table 2. Total failure rate is $\lambda=1.282210^{-3}$ [hour $^{-1}$ ]. It is $\approx 22.8 \%$ higher than the total failure rate of the propulsion engines according to the SRIC (Ship Reliability Investigation Committee) from Japan, where $\lambda=0.98910^{-3}$ [hour $\left.{ }^{-1}\right]$ [4].

The highest failure rate in the research for the exhaust valve was $\lambda=0.487010^{-3}$ [hour $^{-1}$ ] while in the mentioned literature $\lambda=0.421810^{-3}$ [hour $^{-1}$ ] (exhaust valve, fuel oil pump).

\section{MAINTENANCE INTERVAL ADJUSTMENT OF EXHAUST VALVE}

Regarding data completeness the exhaust valve is the best described component of all the analyzed components. The sample is comprehensive, which increases the reliability of the results. The sample of the exhaust valve includes 55 cases, and is shown in Table $3[1]$.

The Weibull distribution can be used in any period of the component's life. All occurrences of failures on the machinery components can be analyzed by defining the shape parameter $\beta$ and scale parameter $\eta$ of the Weibull law. The parameter $t_{o}$ is threshold parameter, and sometimes it is called guarantee time or failure-free time or minimum life. The case with $t_{o}>0$ defines, that the failure cannot happen before certain working time. Because of this $t_{o}$ is called the guarantee parameter. Predicting of the minimum life can be obtained by interviewing the experts. But as chance failures occur during the whole working life, and experts' answers are not safe, for the older plants $t_{o}=0$ can be assured. Then the Weibull distribution has just two parameters $(\mathrm{W}=\mathrm{W}(\eta, \beta))$. In that case the scale parameter presents the maintenance interval (Mean life) (see Figure 2), and the shape parameter defines the shape of the probability density function, cumulative distribution function, reliability function and hazard function.

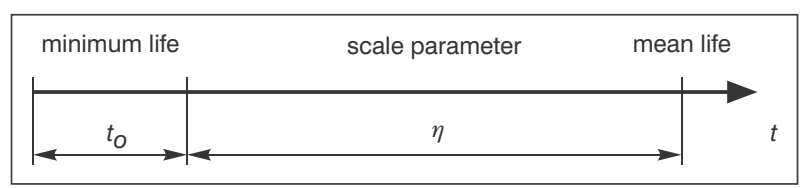

Figure 2 - Initial data

The procedure in sorting out the data is to arrange the TBF (Time between Failure) from the smallest to the biggest (the data set contains suspensions - right censored data or Censored Type I Data), and then to define the medium rank for each failure by means of the Benard's formula (see Table 3). 
Table 3 - A sample for the exhaust valve (complete)

\begin{tabular}{|c|c|c|c|}
\hline $\begin{array}{c}\text { Number of } \\
\text { failures } \\
n_{k}\end{array}$ & $\begin{array}{c}\text { ME } \\
\text { [hours] } \\
\text { (cylinder) }\end{array}$ & $\begin{array}{c}\text { Time between } \\
\text { failure } \\
\text { TBF [hours] } \\
t\end{array}$ & $\begin{array}{c}\text { Median rank } \\
\mathrm{F}(\mathrm{t})=\left(n_{k}-0.3\right) \\
/(n+0.4)\end{array}$ \\
\hline 1 & $74714(5)$ & 723 & 0.0126 \\
\hline 2 & 33575 (3) & 762 & 0.0307 \\
\hline 3 & $73393(2)$ & 775 & 0.0487 \\
\hline 4 & $67714(3)$ & 787 & 0.0668 \\
\hline 5 & 88589 (6) & 934 & 0.0848 \\
\hline 6 & $87655(6)$ & 1006 & 0.1029 \\
\hline 7 & $75442(7)$ & 1137 & 0.1209 \\
\hline 8 & $73991(4)$ & 1255 & 0.1389 \\
\hline 9 & $73991(5)$ & 1271 & 0.1570 \\
\hline 10 & $89501(7)$ & 1342 & 0.1751 \\
\hline- & - & - & - \\
\hline- & - & - & - \\
\hline- & - & - & - \\
\hline 46 & $67188(5)$ & 4582 & 0.8249 \\
\hline 47 & $81802(5)$ & 4725 & 0.8429 \\
\hline 48 & $52898(2)$ & 5098 & 0.8610 \\
\hline 49 & $72618(2)$ & 5213 & 0.8791 \\
\hline 50 & 79979 (1) & 5219 & 0.8971 \\
\hline 51 & $74760(1)$ & 5280 & 0.9152 \\
\hline 52 & 85541 (1) & 5562 & 0.9332 \\
\hline 53 & $88183(4)$ & 6251 & 0.9513 \\
\hline 54 & $78413(6)$ & 6376 & 0.9693 \\
\hline 55 & $55140(3)$ & 6575 & 0.9874 \\
\hline
\end{tabular}

Using the program package "Statistic 7.1" and selecting the Weibull distribution in the very program will yield the following (Figures 3 and 4).

Figure 3 shows that most failures occurred between 2000 and 2500 hours. The threshold parameter $t_{0}=0$, means that failures are possible after the exhaust valve installation. The characteristic life $\eta=$ 3333 hours, and shape parameter $\beta=2$. The obtained Weibull distribution with the shape parameter $\beta=2$ equals Rayleight distribution. This is a special case of Weibull distribution where the hazard function is being continually increased and has the shape of a straight line.

For testing the two-parameter Weibull goodness-of-fit, the correlation statistics of Anderson-Darling test [5] has been done, during which the $A^{2}$ are calculated according to:

$A^{2}=-n-\frac{1}{n} \sum_{i=1}^{n}(2 i-1)\left[\ln \left(w_{i}\right)+\ln \left(1-w_{n-i+1}\right)\right]$,

where $w_{i}$ is Weibull CDF given by equation

$w_{i}=F(x)=1-e^{-\left(\frac{x_{i}}{\eta}\right)^{\beta}}$

In this case $x_{i}=t$ (Table 3).

For small number of samples, value $A^{2}$ has to be modified according to:

$A_{m}^{2}=A^{2}\left(1+\frac{0.2}{\sqrt{n}}\right)$

Inserting the values yields $A_{m}^{2}=0.5266$.

According to [6] OSL (observed significance level) is computed according to:

$O S L=1 /\left\{1+\exp \left[-0.1+1.24 \ln \left(A_{m}^{2}\right)+4.48\left(A_{m}^{2}\right)\right]\right\}$.

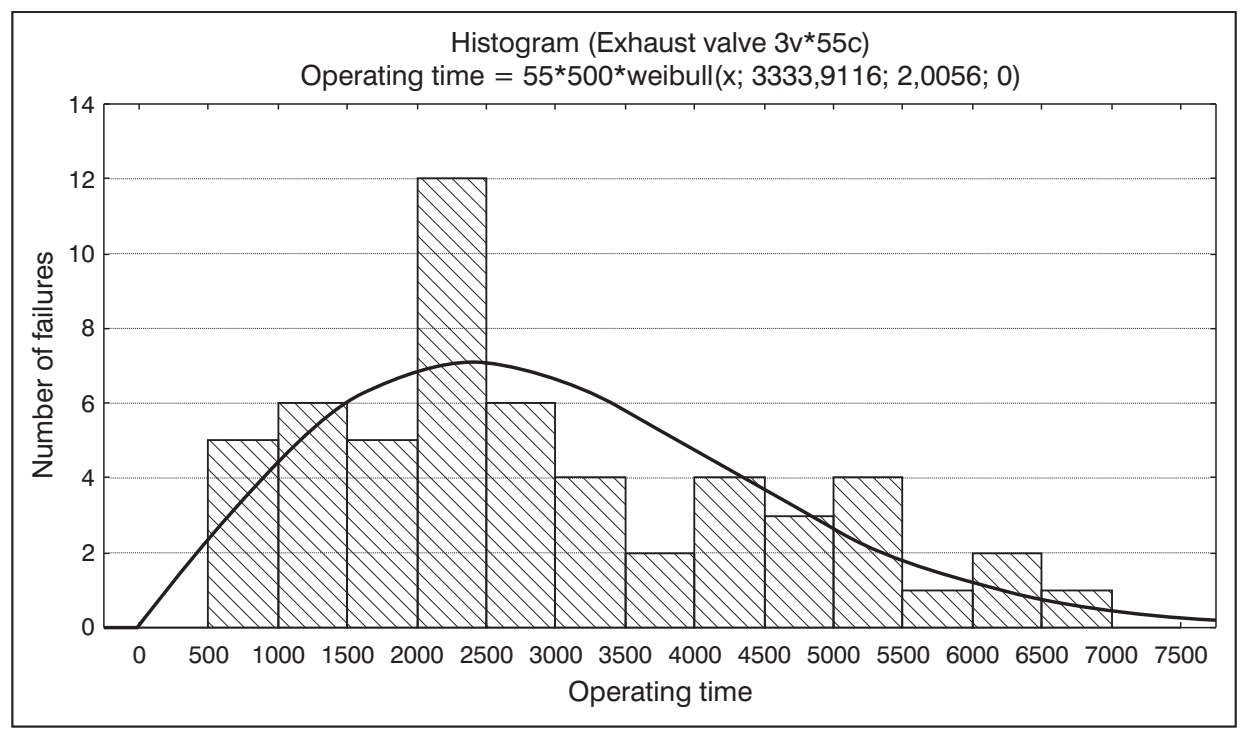

Figure 3 - Exhaust valve failures 
Introducing the value for $A_{m}^{2}$ gives $O S L=0.188$. If the $O S L>0.05$ Weibull distribution is acceptable, with goodness-of-fit $95 \%$.

Using the mentioned program package a value for the standard deviation $\sigma$ and the mean time between failures is obtained. Predictability $p=0.46$ (46\%) obtained from equation 5 shows prediction possibility (expectancy) TBF and TTF (Time to Failure). It assumes the values between $(0,1)$, and is defined as follows [7]:

$$
p=\left\{\begin{aligned}
1-\frac{\sigma}{M T B F} ; & \sigma<M T B F \\
0 ; & \sigma=M T B F
\end{aligned}\right\} \text {. }
$$

FMCC of exhaust valve shows increasing failure rate (Table 4).

Results of the exhaust valve sample are shown in Table 5.
Table 4 - Relationships between prediction and failure distribution [7]

\begin{tabular}{||l|l|c||}
\hline \hline Failure law & \multicolumn{1}{|c|}{ Description } & Predictability \\
\hline \hline DFR /CFR & $\begin{array}{l}\text { FMCC with decreasing } \\
\text { or constant failure rate }\end{array}$ & None $(p=0)$ \\
\hline IFR & $\begin{array}{l}\text { FMCC with increasing } \\
\text { failure rate }\end{array}$ & Low $(0<p<0,5)$ \\
\hline $\begin{array}{l}\text { Significant } \\
\text { IFR }\end{array}$ & $\begin{array}{l}\text { FMCC with significant } \\
\text { increasing failure rate }\end{array}$ & High $(0.5 \leq p \leq 1)$ \\
\hline
\end{tabular}

Table 5 - Results of the exhaust valve sample (complete)

\begin{tabular}{|c|c|c|c|c|c||}
\hline$\beta$ & $t_{0}$ & $\eta$ & $\sigma$ & MTBF & $p$ \\
\hline 2 & 0 & 3333 & 1576 & 2943 & 0.46 \\
\hline
\end{tabular}

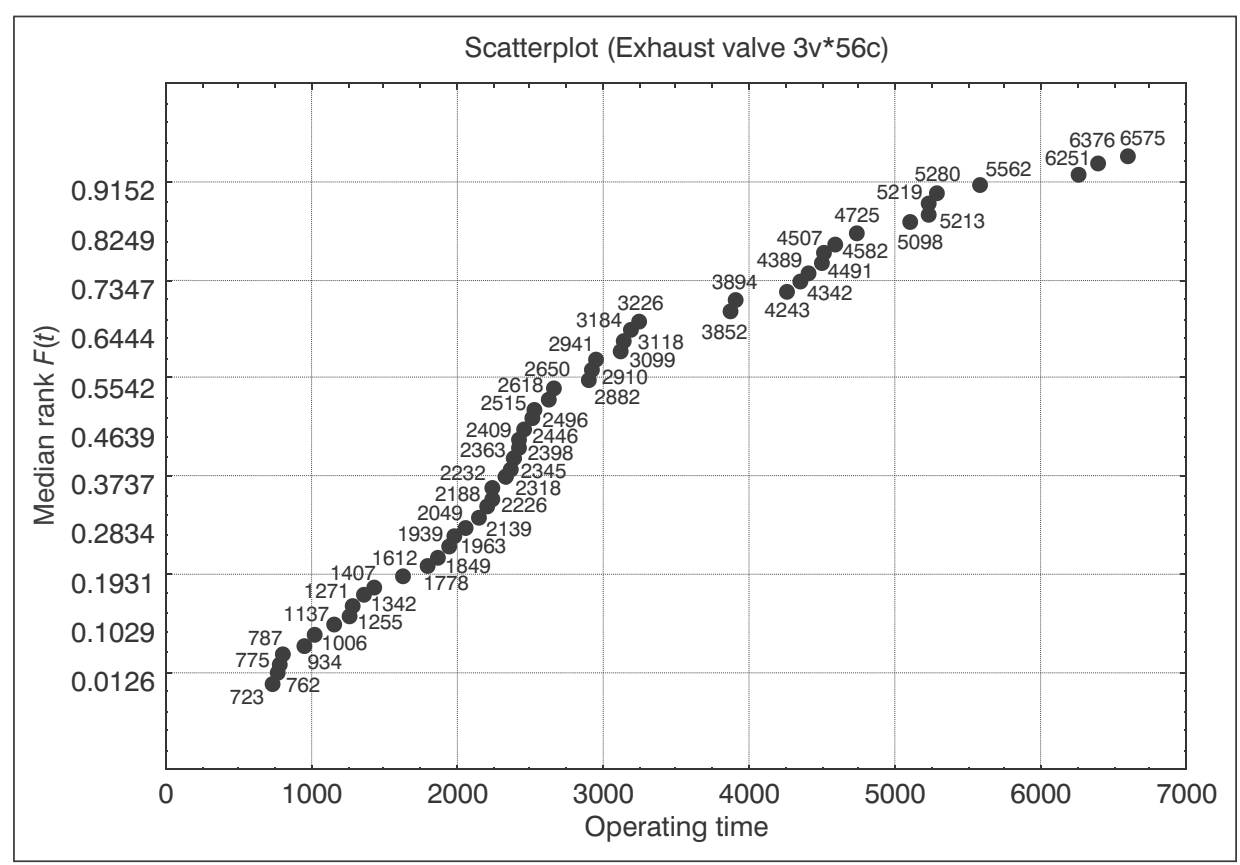

Figure 4 - Data scatterplot in the exhaust valve sample

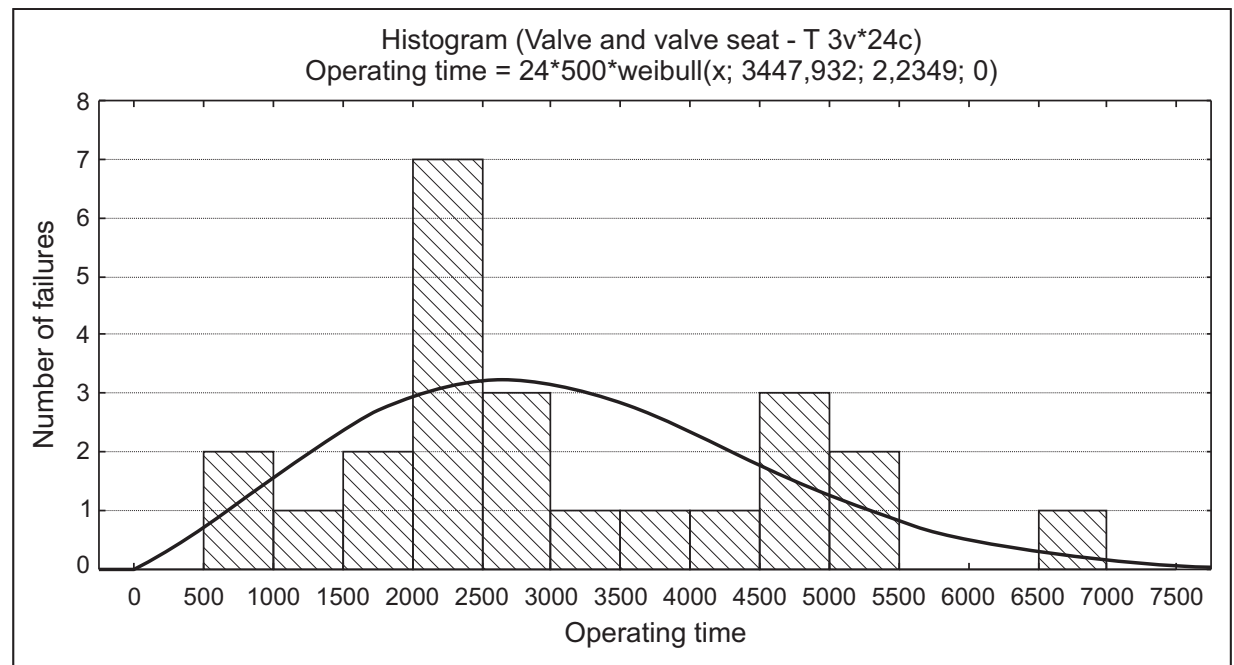

Figure 5 - Valve and valve seat failure 
Table 6 - A sample for the valve and valve seat

\begin{tabular}{|c|c|c|c||}
\hline $\begin{array}{c}\text { Number of } \\
\text { failures } \\
n_{k}\end{array}$ & $\begin{array}{c}\text { ME } \\
\text { [hours] } \\
\text { (cylinder) }\end{array}$ & $\begin{array}{c}\text { Time between } \\
\text { failure } \\
\text { TBF [hours] } \\
t\end{array}$ & $\begin{array}{c}\text { Median rank } \\
\mathrm{F}(\mathrm{t})=\left(n_{k}-0.3\right) / \\
/(n+0.4)\end{array}$ \\
\hline \hline 1 & $73393(2)$ & 775 & 0.0287 \\
\hline 2 & $67714(3)$ & 787 & 0.0697 \\
\hline 3 & $84054(2)$ & 1407 & 0.1106 \\
\hline 4 & $82647(2)$ & 1849 & 0.1516 \\
\hline 5 & $64018(4)$ & 1963 & 0.1926 \\
\hline 6 & $75442(2)$ & 2049 & 0.2336 \\
\hline 7 & $72075(7)$ & 2139 & 0.2746 \\
\hline 8 & $84120(4)$ & 2188 & 0.3156 \\
\hline 9 & $82370(3)$ & 2345 & 0.3565 \\
\hline 10 & $77077(5)$ & 2363 & 0.3975 \\
\hline 11 & $35689(6)$ & 2409 & 0.4385 \\
\hline 12 & $80798(2)$ & 2446 & 0.4795 \\
\hline 13 & $69838(5)$ & 2650 & 0.5205 \\
\hline 14 & $78352(2)$ & 2910 & 0.5615 \\
\hline 15 & $81932(4)$ & 2941 & 0.6025 \\
\hline 16 & $85469(3)$ & 3099 & 0.6434 \\
\hline 17 & $54541(6)$ & 3852 & 0.6844 \\
\hline 18 & $62056(4)$ & 4243 & 0.7254 \\
\hline 19 & $62405(2)$ & 4507 & 0.7664 \\
\hline 20 & $67188(5)$ & 4582 & 0.8074 \\
\hline 21 & $81802(5)$ & 4725 & 0.8484 \\
\hline 22 & $52898(2)$ & 5098 & 0.8893 \\
\hline 23 & $72618(2)$ & 5213 & 0.9303 \\
\hline 24 & $55140(3)$ & 6575 & 0.9713 \\
\hline
\end{tabular}

Figure 4 shows the data scattering of the exhaust valve sample, where the time between failures is written next to each data. The graphic survey shows that most failures occurred between 2000 and 2500 hours.

According to Table 1 the most jeopardized part of the plant is the valve. The sample data for the valve and valve seat are shown in Table 6 .

Using the mentioned program for the data processing and by the choice of the Weibull distribution in the very program for the valve and seat, the diagrams in Figures 5 and 6 are obtained.

From Figures 5 and 6 it can be observed that most failures (burnt valve disc) occurred between 2000 and 3000 hours $(\approx 50 \%)$. The readout from the program package gives us the scale parameter $\eta=3447$ hours, the shape parameter $\beta=2,23$ and the threshold parameter $t_{0}=0$ of the Weibull distribution. According to (1) the probability of failure expectancy is $0.51(51 \%)$. The FMCCs of valve and valve seat show a significant hazard function (significant IFR) (Table 4). The results for the valve and valve seat are shown in Table 7 :

Table 7 - Results for the valve and valve seat of exhaust valve

\begin{tabular}{|c|c|c|c|c|c||}
\hline$\beta$ & $t_{0}$ & $\eta$ & $\sigma$ & MTBF & $p$ \\
\hline 2.23 & 0 & 3447 & 1485 & 3046 & 0.51 \\
\hline
\end{tabular}

Research results of maintenance interval adjustment of the exhaust valve are shown in Table 7 . The characteristic life of the complete exhaust valve is 3333 hours, while the characteristic life of the valve and valve seat is a little longer (3447).

The maintenance interval (dismantling all the exhaust valves, overhaul and reinstall) due to the expected wearing of the exhaust valve is planned every 5000 hours [8]. The maintenance interval must be shifted to $\approx 3500$ hours.

The exhaust valve shows significant increased failure rate, with the highest failure mode burning of disc and significant effect: bed burning and power drop [1].

According to [7] if the failure rate is in decrease (DFR - Decreasing Failure Rate) or constant (CFR Constant Failure Rate), the predictability is none ( $p=$ $0, \beta$ ? 1 and $\left.t_{0}=0\right)$. Periodic maintenance is inefficient in such cases, so that it will not be added to the series of efficient maintenance policies. At the same time, if predictability is low $\left(0<p ? 0.5,1<\beta<2\right.$ and $\left.t_{0}=0\right)$, periodic maintenance may be considered. However, on-condition PM is more suitable than periodic PM. Periodic PM is chosen in the case of high predictability (significant IFR, $p>0.5$ ). High predictability suits the Weibull shape parameter $\beta \geq 2$ if $t_{0}=0$.

So, for an exhaust valve preventive periodic maintenance can be proposed with interval of 3500 hours, because of high predictability $p=0.51$ and shape parameter $\beta=2.23$.

Table 8 - Maintenance interval adjustment of the exhaust valve

\begin{tabular}{|l|c|c|c|c|c|c|c||}
\hline \multicolumn{1}{|c|}{ Component } & $\beta$ & $t_{0}$ & $\eta$ & $t_{0}+\eta$ & $\begin{array}{c}\text { Predictability } \\
p\end{array}$ & $\begin{array}{c}\text { Manufacturer's } \\
\text { recommendation } \\
{[6]}\end{array}$ & $\begin{array}{c}\text { Research } \\
\text { recommendation } \\
\text { (new interval) }\end{array}$ \\
\hline \hline Exhaust valve (complete) & 2 & 0 & 3333 & 3333 & 0.46 & 5000 & 3300 \\
\hline Valve and valve seat & 2.23 & 0 & 3447 & 3447 & 0.51 & 5000 & 3400 \\
\hline
\end{tabular}




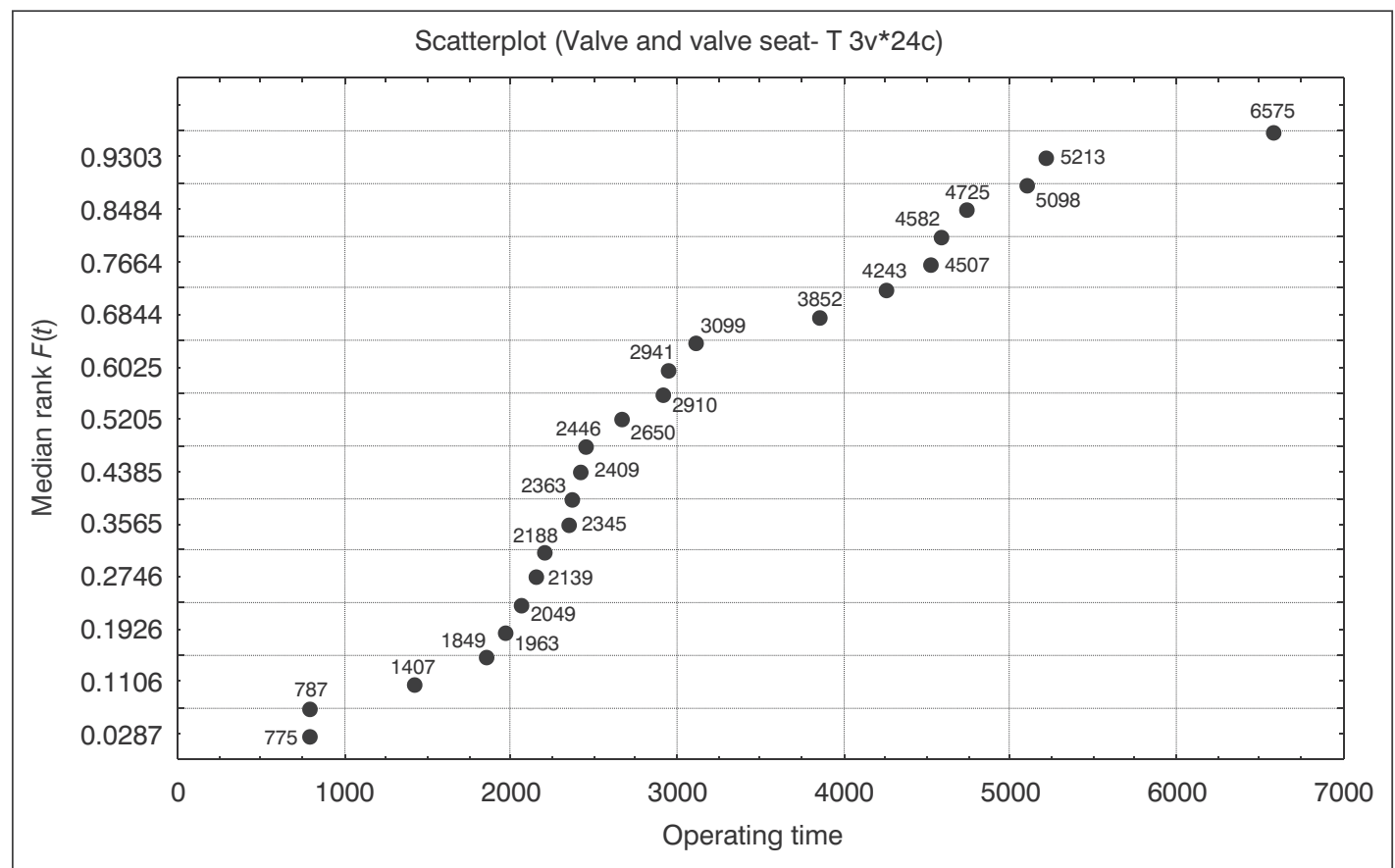

Figure 6 - Data scatterplot in the valve and valve seat sample

\section{CONCLUSION}

Research has been done on operating data collected on the main engine during thirteen years. All records about engine failures have been used from the operating diary.

Research results of the machinery breakdown show that most failures occurred on the exhaust valve, the injection valve and the fuel oil pump. It has been proven that the most jeopardised element of the propulsion engine is the exhaust valve with the highest failure rate. Modelling the maintenance interval of significant components shows that the manufacturer's advice is not reliable, because the research recommended maintenance interval of the significant components is shorter than the manufacturer's recommendation. This proves that the on-time maintenance concept, which is generally used aboard ships, does not represent the most efficient maintenance strategy. The suggested manufacturer's intervals can be modified due to a great number of factors that influence the condition and performance of the component.

Nevertheless, if the operating data about the behaviour of equipment are missing the recommendations given by the producer have to be obeyed. Occasional adjustments of maintenance intervals give a gain in cost minimization.

Dr. sc. IVICA ŠEGULJA

E-mail: is@pfri.hr

Dr. sc. ANTE BUKŠA

Dr. sc. VINKO TOMAS

Sveučilište u Rijeci, Pomorski fakultet

Studentska 2, 51000 Rijeka, Republika Hrvatska

\section{SAŽETAK}

\section{PODEŠAVANJE INTERVALA ODRŽAVANJA ZNAČAJNIH KOMPONENTI}

Koncepcija održavanja po vremenu, koja je najzastupljenija na brodovima, a bazirana je uglavnom na preporukama proizvođača opreme i uređaja, ne predstavlja najdjelotvorniji način održavanja. Predloženi intervali proizvođača mogu biti modificirani zbog niza čimbenika koji utječu na stanje i performanse opreme i uređaja. U radu [1] je razvijen model za oblikovanje i podešavanje koncepta održavanja brodskog pogona, koji omogućava traženu razinu sigurnosti i najniže troškove u životnom ciklusu. Predloženi model za modeliranje podešavanja intervala održavanja kod značajnih komponenti je dio spomenutog modela, te je isti verificiran na podacima iz trinaest godišnje prakse. U istraživanju preporučeni interval održavanja manji je od preporuke proizvođača.

\section{KLJUČNE RIJEČI}

održavanje, dizel-motorni porivni sustav, značajne komponente, učestalost kvara, vrijeme između kvarova, podešavanje intervala održavanja ispušnog ventila

\section{REFERENCES}

1. Bukša A., Modeliranje održavanja brodskog porivnog sustava, Doktorska disertacija, Sveučilište u Rijeci, Pomorski fakultet u Rijeci, Rijeka 2005.

2. ... Dnevnici stroja MAN 7L 400/500, Od 1982. - 1994. godine.

3. Bukša A., Tudor M., Martinović D., Research of the Failure Incidences in the Diesel-engine Propulsion System, The 7th International Conference on Engine 
Room Simulators, 14.-15. november 2005, Portorož, Slovenija.

4. Ozaki, Yoski, An introduction to the ABS Guide for Propulsion Redundancy, Guide for Propulsion Redundancy, The Motor Ship, June, 1997., str. 101 - 112.

5. Evans J. W., Johnson R. A., Green D. W., Two - and Three - Parameter Weibull Goodness-of-fit Tests, United States Department of Agriculture, Reserch Paper FPL - RP - 493.
6. http://theriac.org/DeskReference/ viewDocument.php? id $=60 \&$ SectionsList $=4$

7. Vučinić, B., $M A$ - CAD, Maintenance Concept Adjustment and Design, Delft, Faculty of Mechanical Engineering and Marine Technology, 1994.

8. ... Operating manual for diesel engines, Type $7 L$ 400/500, Maschinenfabrik Augsburg-Nürberg Aktiengesellschaft D - 8900 Augsburg 1, Stadtbachstrasse 1, D $365617 \mathrm{E}$. 